\title{
Pengaruh Kedalaman terhadap Perkembangan Rumput Laut Kotoni Hasil Kultur Jaringan
}

\author{
[The influence of depth on the development of kotoni seaweed \\ resulting from tissue culture]
}

\author{
Nico Runtuboy, Slamet Abadi
}

Balai Besar Pengembangan Budidaya Laut Lampung

Jalan Yos Sudarso, Desa Hanura, Padang Cermin, Kabupaten Pesawaran, Lampung

Diterima: . 18 September 2018; Disetujui: 3 Desember 2018

\begin{abstract}
Abstrak
Biotrop Bogor berhasil melakukan kultur jaringan bibit rumput laut Kotoni (Kappaphycus alvarezii) hingga skala laboratorium.Perkembangan hingga produksi masal telahberhasil dilakukan oleh BBPBL Lampung. Sebagai komoditas baru, perlu dilakukan uji coba pendahuluan. Salah satu yang telah dilakukan adalah melakukan uji coba pada tahun 2014 untuk mengetahui kedalaman terbaik terhadap perkembangan bibit rumput laut hasil kultur jaringan. Uji coba dilakukan selama VI minggu dengan menggunakan berat awal bibit yang sama yaitu 75 gram pada tiga tingkatan kedalaman perairanberbeda: $10 \mathrm{~cm}, 30$ dan $50 \mathrm{~cm}$. Parameter yang diamati meliputi, perkembangan tanaman, dan sintasan. Hasil pengamatan perkembangan tanaman pada kedalaman 10 $\mathrm{cm}$ dari minggu pertama sampai minggu ke $\mathrm{VI}$ berat awal $75 \mathrm{gr}, 115,80 \mathrm{gr}, 157,40 \mathrm{gr}, 216,00$ $\mathrm{gr}, 303,00 \mathrm{gr}, 341,00 \mathrm{gr}$ dan $375,00 \mathrm{gr}$. Kedalaman $30 \mathrm{~cm}$ berat awal $75 \mathrm{gr}, 118,60 \mathrm{gr}, 139,80 \mathrm{gr}$, $199,00 \mathrm{gr}, 254 \mathrm{gr} 293 \mathrm{gr}$ dan $304 \mathrm{gr}$. Kadalaman $50 \mathrm{~cm}$ : berat awal $75 \mathrm{gr}, 96,6 \mathrm{gr}, 122,4 \mathrm{gr}, 159$ $\mathrm{gr}, 207 \mathrm{gr}, 250 \mathrm{gr}$ dan 260,8 gr. Sintasan (SR) pada kedalaman $10 \mathrm{~cm}$ dari minggu pertama hingga minggu keempat $100 \%$ dan pada minggu ke lima dan keenam masing-masing $98 \%$. SR pada kedalaman $30 \mathrm{~cm}$ dari minggu pertama hingga keempat $100 \%$ dan minggu kelima dan keenam $96 \%$. Dan SR pada kedalaman $50 \mathrm{~cm}$ dari minggu pertama hingga minggu ke empat $100 \%$ dan pada minggu ke lima $94 \%$ dan $92 \%$. Berdasarkan hasil perhitungan, melakukan kegiatan produksi dapat melakukan penanaman pada kedalaman antara 10 hingga $30 \mathrm{~cm}$.
\end{abstract}

Kata penting: bibit rumput laut; kedalaman; kultur jaringan

\section{Abstract}

Biotrop Bogor successfully cultured the tissue of Kotoni seaweed seeds (Kappaphycus alvarezii) to the laboratory scale level. Developments from the lab scale to mass production have been successfully carried out by BBPBL Lampung. As a new commodity, preliminary trials need to be carried out. One of the things that has been done is conducting a trial to find out the best depth of the development of tissue culture seaweed seeds. The trial was conducted for VI weeks using the same initial weight of seeds which was 75 grams on three different levels of water depth: 10 $\mathrm{cm}, 30$ and $50 \mathrm{~cm}$. Parameters observed included plant development, and survival rate. The results of observations of plant development at a depth of $10 \mathrm{~cm}$ from the first week to the week to VI the initial weight of $75 \mathrm{~g}, 115.80 \mathrm{~g}, 157.40 \mathrm{~g}, 216.00 \mathrm{~g}, 303.00 \mathrm{~g}, 341.00 \mathrm{~g}$ and $375.00 \mathrm{~g} .30$ cm depth initial weight $75 \mathrm{gr}, 118,60 \mathrm{gr}, 139,80 \mathrm{gr}, 199,00 \mathrm{gr}, 254 \mathrm{gr} 293 \mathrm{gr}$ and $304 \mathrm{gr} .50 \mathrm{~cm}$ depth: initial weight $75 \mathrm{gr}, 96,6 \mathrm{gr}, 122,4 \mathrm{gr}, 159 \mathrm{gr}, 207 \mathrm{gr}, 250 \mathrm{gr}$ and 260,8 gr. Survival rate (SR) at a depth of $10 \mathrm{~cm}$ from the first week to the fourth week was $100 \%$ and at the fifth and sixth weeks $98 \%$ respectively. SR at a depth of $30 \mathrm{~cm}$ from the first week to the fourth $100 \%$ and the fifth and sixth weeks $96 \%$. And SR at a depth of $50 \mathrm{~cm}$ from the first week to the fourth week $100 \%$ and at the fifth week $94 \%$ and $92 \%$. Based on the results of calculations, carrying out production activities can be planted at a depth of be 10 to $30 \mathrm{~cm}$.

Keywords: depth; seaweed seeds; tissue culture 


\section{PENDAHULUAN}

Salah satu komoditi perikanan budidaya yang menjadi primadona saat ini adalah rumpt laut Kotoni (Kappaphycus alvarezii). Jenis ini menjadi primadona karena permin-taan pasar baik luar negeri maupun dalam negeri cukup tinggi. Secara tek-nis metode budidaya mudah, murah, umur panen pendek, panen dan pasca panen sederhana dan menyerap ba-nyak tenaga kerja. Saat ini usaha bu-didaya rumput laut jenis ini telah ber-kembang hampir merata diseluruh Indonesia. Dalam perkembangannya pembudidaya rumput laut sering mengalami beberapa kendala dimana salah satu kendalanya adalah keterba-tasan ketersediaan bibit rumput laut bermutu.

Upaya-upaya untuk mendapat-kan bibit unggul terus dilakukan oleh pemerintah baik melalui seleksi indi-vidu, klon melalui pembuatan kebun bibit secara vegetatif. Berita gembira muncul ketika pada tahun 2011 Southeast Asian Regional Center for Tropical Biology (SEAMEO BIO-TROP) Bogor berhasil melakukan kul-tur jaringan (kuljar) rumput laut jenis ini. Keberhasilan ini langsung disam-but oleh BBPBL Lampung dan me-lakukan kerja sama dimana beberapa sampel dikirim ke Lampung. Pada ta-hap awal bibit tersebut dipelihara da-lam akuarium selama 2-3 bulan lalu dilanjutkan dengan pemeliharaan di green house. Saat ini sedang mela-kukan uji multi lokasi terhadap rumput laut kultur jaringan dibeberapa titik lo-kasi di Lampung yaitu Pahawang, Ke-tapang, Sragi dan Legundi serta satu lokasi di Banten yaitu daerah Lontar. Setelah di green house tanaman tersebut diaklimatisasikan di beberapa tempat seperti bak semi indoor, bak outdoor dan di laut. Perlakuan aklima-tisasi tersebut memberikan hasil yang baik dimana tanaman tersebut tetap berkembang hingga saat ini. Mengantisipasi perkembangan bibit-bibit tersebut maka pada tahun 2014 BBPBL Lampung melakukan perekayasaan perbanyakan bibit rum-put laut Kotoni.

Tujuan penelitian ini adalah un-tuk mendapatkan data tentang keda-laman yang ideal untuk perkembangan bibit rumput laut hasil kultur jaringan. Sedangkan sasaran yang ingin dicapai adalah memberikan informasi yang tepat tentang kedalaman yang ideal un-tuk kegiatan membudidayakan rum-put laut kotoni hasil kultur jaringan. Kegiatan 
dilakukan selama 1,5 bulan, berlokasi di Balai Besar Perikanan Bu-didaya Laut Lampung.

\section{BAHAN DAN METODE}

Direktorat Jenderal Perikanan Budidaya (2008) menyatakan bahwa budidaya rumput laut Eucheuma cottonii dengan metode rakit terapung menunjukkan pertumbuhan yang tertinggi pada perlakuan bobot awal 60 gram pada jarak tanam $30 \mathrm{~cm}$ di Perairan Teluk Hurun, Lampung. Pemi-lihan lokasi untuk uji kedalaman ini dilakukan dengan memenuhi persya-ratan lokasi yang mendukung pertum-buhan rumput laut, salah satunya ada-lah berada di perairan laut dengan ke-tersediaan air laut yang segar, tanpa pencemaran. Hal ini juga merujuk kepada hasil penelitian Budiyani dkk (20-11) yang menyatakan pertumbuh-an rumput laut sejenis Caulerpa sp. akan optimal bila berada pada perairan laut dengan konsentrasi nitrat yang cukup. Pada penelitian di BBPBL metode dalam uji kedalaman ini yang digunakan adalah metode rakit bambu apung. Penentuan penggunaan rakit bambu bertujuan agar jika tanaman tersebut digantungkan pada konstruksi akan mendapatkan kedalaman yang diharapkan. Selain itu juga, hasil ka-jian Abdullah (2011) menyatakan bahwa teknik budidaya rumput laut Kappaphycus alvarezii dengan metode rakit apung ukuran $10 \times 7 \mathrm{~m}$ dengan jarak $10-14 \mathrm{~cm}$, cukup berhasil. Bibit yang digunakan berumur 20 hari de-ngan berat $100 \mathrm{gr}$, dalam kurun waktu pemeliharaan 30 hari, diperoleh hasil 1 ton. Pada penelitian di BBPBL Lampung, kegiatan diawali dengan mem-buat rakit bambu apung ukuran $3 \times 5 \mathrm{~m}$ yaitu sebanyak satu unit. Pe-ngamatan tentang kedalaman berbeda tersebut dilakukan dengan tiga per-lakuan yaitu pada kedalaman $10 \mathrm{~cm}, 30 \mathrm{~cm}$ dan 50 $\mathrm{cm}$ dengan masing-masing tiga ulangan. Penetapan ke-dalaman ini mengacu kepada beberapa kajian yang telah dilakukan tentang hubungan pertumbuhan Kappaphycus alvarezii dengan kedalaman.

Salah satu peneliti yang meng-kaji tentang kedalaman, diantaranya adalah kajian dari Harahap (2010) yang menyatakan bahwa kedalaman sekitar 1 $2 \mathrm{~m}$ memberikan pertum-buhan yang terbaik. Setelah kon-struksi dibuat, tahap berikutnya me-nyiapkan tali jalur yaitu tali dari bahan PE $4 \mathrm{~mm}$ yang digunakan untuk mengikat bibit rumput laut. Selanjutnya bibit diseleksi dan ditimbang masing-masing 75 gram. Salah satu faktor yang dapat berpengaruh ter-hadap pertumbuhan rumput laut Euc-heuma cottonii yang dibudidayakan adalah bobot awal. Penelitian Sulis-tiowati (2012) menyatakan bahwa pertumbuhan tertinggi Gracillaria verru-cosa 
di pertambakan Kalirejo, Kendal dicapai pada kepadatan awal thallus $50 \mathrm{gr}$ setiap rumpun. Menurut hasil dari penelitian Soenardjo (2011) me-nyatakan berat awal $100 \mathrm{~g}$ dengan ja-rak $2 \mathrm{~m}$, memiliki laju pertumbuhan harian yang cukup baik. Selain itu, menurut Pongarrang dkk. (2013), jarak tanam terbaik untuk jenis rumput laut Kappaphycus alvarezii dengan meng-gunakan metoda vertikultur adalah $20 \mathrm{~cm}$.

Bibit yang telah ditimbang diikat pada tali jalur lalu tali jalur tersebut digantungkan pada konstruksi rakit bambu yang telah disiapkan dengan kedalaman 10, 30 dan $50 \mathrm{~cm}$. Agar posisi tali jalur berdiri tegap maka pa-da bagian bawah setiap tali diberi pemberat. Menurut Direktorat Jenderal Perikanan Budidaya (2008), jika rum-put laut digunakan untuk bibit, maka rumput laut dipanen setelah berumur 25-35 hari. Sedangkan supaya kan-dungan karaginan tersedia lebih banyak, maka panen sebaiknya ber-umur enam minggu atau 45 hari. Bibit yang digunakan adalah bibit rumput laut kotoni hasil kultur jaringan de-ngan kriteria: (a) umur panen 25 hari; (b) bercabang banyak dan rimbun; (c) thalus mulus (tidak

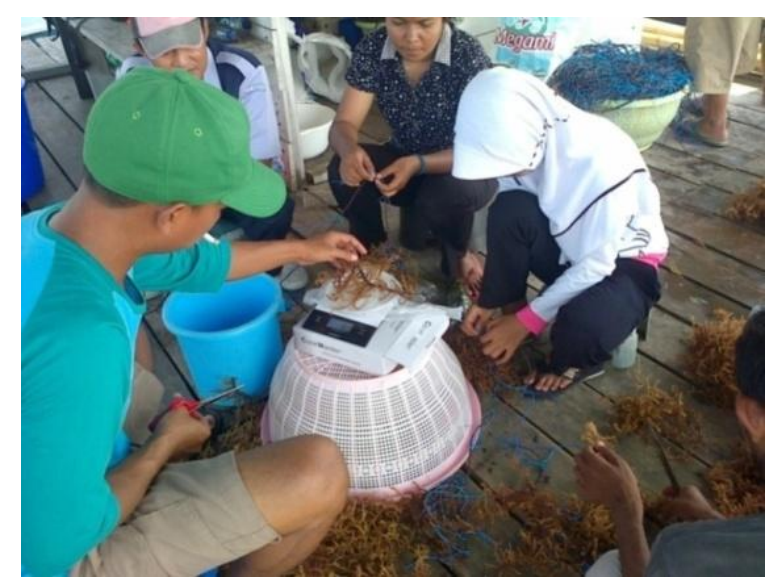

Gambar 1. Seleksi dan penimbangan bibit pada awal kegiatan penelitian

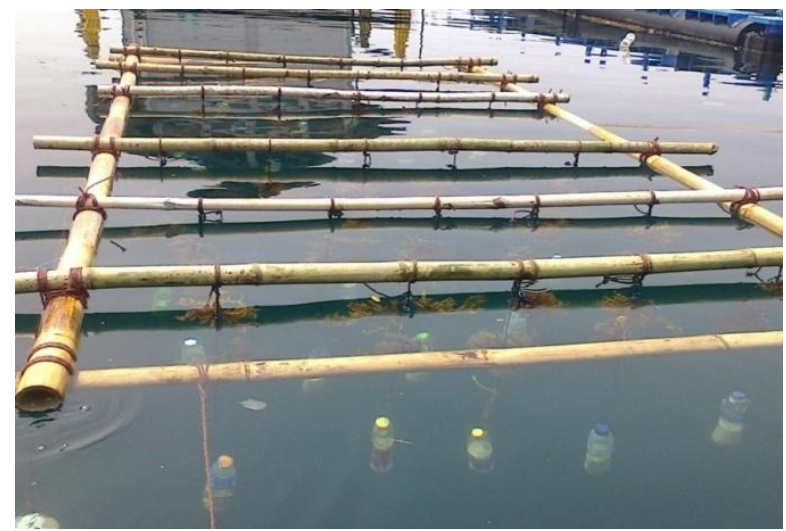

Gambar 2. Konstruksi rakit bambu apung yang telah ditanam tanaman uji 
terkelupas); (d) masih segar; dan (e) ujung thalus runcing. Persiapan bibit rumput laut dapat dilihat pada Gambar 1.

Menurut Runtuboy (2008), salah satu kunci sukses usaha budidaya rumput laut kotoni adalah pengon-trolan rutin terhadap tanaman, maka demi kenyamanan tanaman uji coba tersebut kegiatan pengontrolan dilaku-kan setiap hari sebagai tindakan pre-ventif untuk mencegah adanya serang-an ikan herbivora seperti ikan baro-nang dan penyu.

Parameter utama yang diamati adalah presentase laju pertumbuhan harian (pertambahan berat) dan sintasan (SR). Sedangkan untuk mengetahui perkembangan tanaman tersebut maka dilakukan sampling pertumbuhan setiap minggu. Kegiatan sampling dilakukan dengan cara mengangkat semua tanaman untuk diukur. Untuk mengetahui laju presentase pertumbuhan harian digunakan rumus:

$$
a=\left\{[\mathrm{Wt} / \mathrm{Wo}]^{1 / t}-1\right\} \times 100 \%
$$

dimana:

$$
\begin{aligned}
\mathrm{a}= & \text { laju pertumbuhan harian }(\%) \\
\mathrm{Wt}= & \text { berat individu rata-rata }(\mathrm{g}) \\
\mathrm{Wo}= & \text { berat individu rata-rata awal } \\
& \text { penebaran }(\mathrm{g}) \\
\mathrm{t}= & \text { waktu }
\end{aligned}
$$

Untuk mengetahui Tingkat Kelulusan Hidup digunakan rumus:

$$
\mathrm{SR}(\%)=\frac{\sum \mathrm{t}}{\sum \mathrm{o}} \times 100 \%
$$

Mengingat rumput laut ini sa-ngat peka terhadap sinar matahari, ma-ka kegiatan sampling dilakukan sece-pat mungkin agar pada pagi hari di tempat yang terlindung dari sinar ma-tahari langsung. Air merupakan media tempat hidup rumput laut tersebut se-hingga selama masa uji coba juga di-lakukan pengamatan setiap minggu terhadap beberapa parameter yang ber-pengaruh terhadap perkembangan rumput laut. Faktor fisik meliputi gerakan air yang disebabkan oleh arus, kedalaman air, suhu air besarnya kece-patan arus, dan dasar perairan. Ke-seluruhannya guna mendukung per-tumbuhan rumpu laut.

\section{HASIL DAN PEMBAHASAN \\ Hasil}

Hasil pengamatan kegiatan perekayasaan perbanyakan bibit rumput laut Kotoni (Kappaphycus alvarezii) hasil kultur jaringan semi masal di laut dengan perlakuan kedalaman berbeda ini menitik-beratkan pada beberapa faktor kualitas air terlihat pada Tabel 1., pertambahan berat, persentase laju pertumbuhan harian, terlihat pada Tabel 2. dan pertambahan bobot pada Gambar 3. Sedangkan Sintasan dapat dilihat 
Tabel 1. Hasil pengamatan kualitas air selama uji coba

\begin{tabular}{llc}
\hline No & \multicolumn{1}{c}{ Parameter } & Nilai \\
\hline 1. & Salinitas & $29-30(\mathrm{ppt})$ \\
2. & $\mathrm{pH}$ & $7.83-8.01$ \\
3. & Suhu Air & $28-29\left({ }^{\circ} \mathrm{C}\right)$ \\
4. & Kecerahan & $3-5 \mathrm{~m}$ \\
\hline
\end{tabular}

Tabel 2. Data pertumbuhan rumput laut pada perlakuan kedalaman berbeda

\begin{tabular}{|c|c|c|c|c|c|c|c|c|}
\hline \multirow{2}{*}{ No } & \multirow{2}{*}{ Perlakuan } & \multirow{2}{*}{$\begin{array}{l}\text { Berat } \\
\text { Awal }\end{array}$} & \multicolumn{6}{|c|}{ Minggu ke: Berat dalam gr (\%) } \\
\hline & & & I & II & III & IV & $\mathbf{v}$ & VI \\
\hline 1 & $\begin{array}{l}\text { Kedalaman } \\
10 \mathrm{~m}\end{array}$ & $75 \mathrm{gr}$ & $\begin{array}{l}115,8 \\
(6,4)\end{array}$ & $\begin{array}{l}157,4 \\
(5,4)\end{array}$ & $\begin{array}{l}216 \\
(5,2)\end{array}$ & $\begin{array}{l}303 \\
(5,1)\end{array}$ & $\begin{array}{l}341 \\
(4,4)\end{array}$ & $\begin{array}{l}375 \\
(5,4)\end{array}$ \\
\hline 2 & $\begin{array}{l}\text { Kedalaman } \\
50 \mathrm{~m}\end{array}$ & $75 \mathrm{gr}$ & $\begin{array}{c}118,6 \\
(6,7)\end{array}$ & $\begin{array}{c}139,8 \\
(4,5)\end{array}$ & $\begin{array}{l}199 \\
(4,8)\end{array}$ & $\begin{array}{l}254 \\
(4,5)\end{array}$ & $\begin{array}{c}293 \\
(3,97)\end{array}$ & $\begin{array}{c}304 \\
(3,38)\end{array}$ \\
\hline 3 & $\begin{array}{l}\text { Kedalaman } \\
30 \mathrm{~m}\end{array}$ & $75 \mathrm{gr}$ & $\begin{array}{l}96,6 \\
(3,7)\end{array}$ & $\begin{array}{c}122,4 \\
(3,6)\end{array}$ & $\begin{array}{l}159 \\
(3,6)\end{array}$ & $\begin{array}{l}207 \\
(3,7)\end{array}$ & $\begin{array}{c}250 \\
(3,5)\end{array}$ & $\begin{array}{c}260,8 \\
(3)\end{array}$ \\
\hline
\end{tabular}

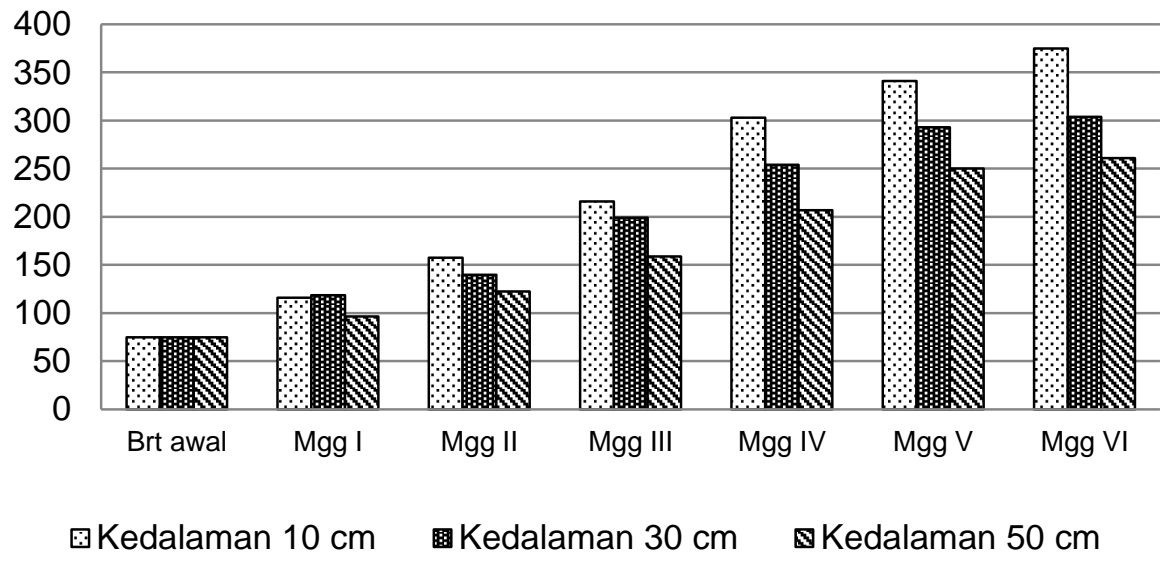

Gambar 3. Grafik pertambahan bobot pada perlakuan kedalaman berbeda

pada Tabel 3 dan Gambar 4. Tampilan profil rumput laut keda-laman $10 \mathrm{~cm}$ terlihat pada Gambar 5.

\section{Pembahasan}

Hasil pengamatan kualitas seper-ti terlihat pada Tabel 1. menunjukkan bahwa salinitas berkisar antara 28-35 ppt, pH air 7-8, oksigen terlarut (DO) 6 ppm. Tampilan fisik perairannya subur dan bebas dari jangkauan pen-cemaran. 


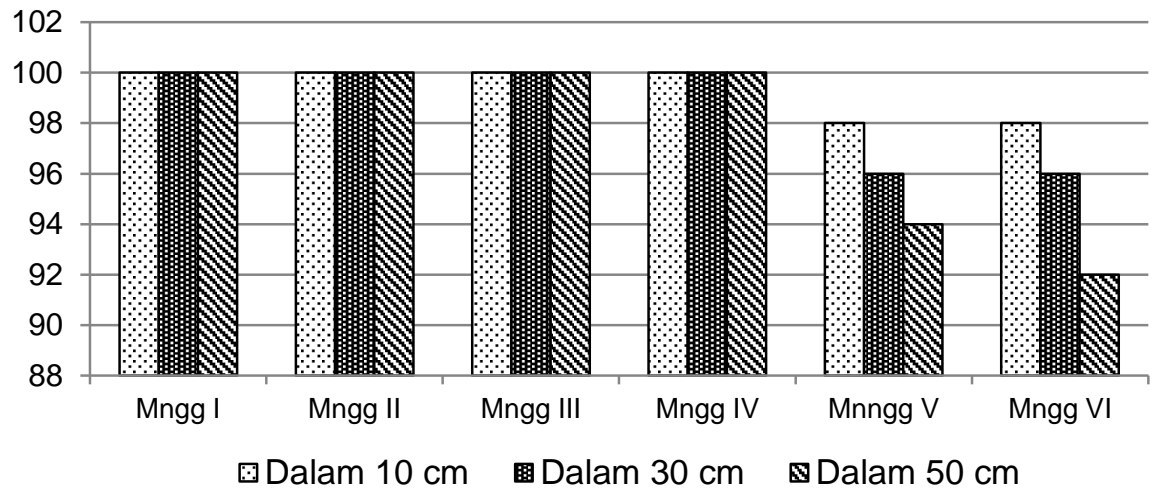

Gambar 4. Grafik sintasan pada perlakuan kedalaman berbeda

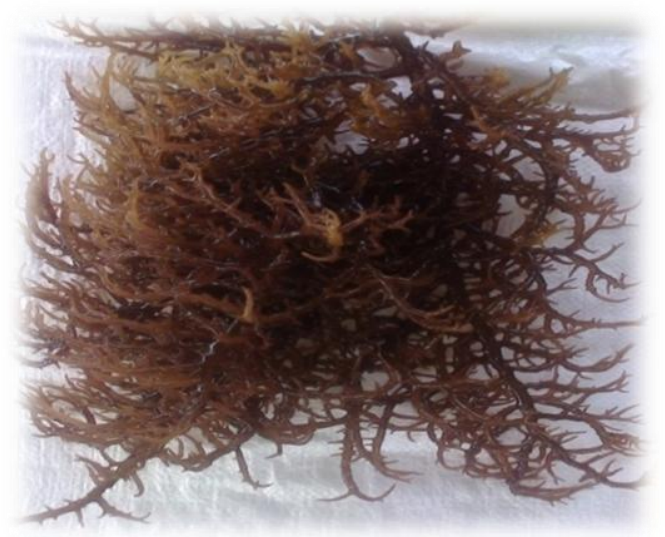

Gambar 5. Tampilan morfologi rumput laut hasil uji kedalaman $10 \mathrm{~cm}$

Selama kegiatan dilakukan pengambilan sampel setiap minggu. Pengambilan sampel air dan pengukurannya dilakukan oleh Tim Kese-hatan Lingkungan BBPBL Lampung. Data hasil pengamatan kualitas air se-lama masa uji coba ditampilkan pada Tabel 1.

Jika dilihat secara keseluruhan, perkembangan rumput laut dari tiga perlakuan menunjukan peningkatan yang relatif sama mulai dari minggu pertama hingga minggu keenam. Teta-pi berdasarkan analisa data diatas tam-pak bahwa perkembangan rumput laut pada kedalaman $10 \mathrm{~cm}$ cenderung le-bih baik dari kedua kedalaman $30 \mathrm{~cm}$ rata-rata 4 $\%$ dan terakhir kedalaman $50 \mathrm{~cm}$ ratarata $3 \%$ (Gambar 3.)

Hal ini terjadi karena pada kedalaman $10 \mathrm{~cm}$ dan $30 \mathrm{~cm}$ posisi tanam-an lebih dekat ke permukaan air sehingga sinar matahari yang dite-rimapun lebih baik dan memberi pe-ngaruh lebih baik pula pada kedua perlakuan tersebut dibanding perla-kuan tiga yaitu kedalaman $50 \mathrm{~cm}$. Pertumbuhan dan produksi rumput laut berhubungan erat dengan proses fotosintesis. Proses fotosintesa jauh le-bih cepat terjadi pada intensitas cahaya yang tinggi daripada 
ketika tumbuh pada intensitas cahaya yang rendah. Menurut Serdiati \& Widiastuti (2010) pertumbuhan dan produksi Eucheuma cottonnii tertinggi terjadi pada keda-laman $30 \mathrm{~cm}$. Pertumbuhan Kappa-phycus alvarezii juga sering terkendala dengan adanya penyakit ice-ice yang berakibat penurunan pertumbuhan dan pada akhirnya mempengaruhi produk-si. Oleh karena itu, perlu diantisipasi adanya iceice ini, agar tidak meng-ganggu pertumbuhan.

Menurut hasil penelitian Aris (2011), keberadaan ice-ice dapat dengan cepat dideteksi langsung dari jaringan rumput laut (6 jam) dengan evaluasi perbandingan bakteri Pseudomonas pavia. Tampilan morfologi rumput laut hasil uji kedalaman $10 \mathrm{~cm}$ dapat dilihat dan disimak pada Gam-bar 5.

Laju pertumbuhan rumput laut Kotoni di setiap lokasi berbeda-beda. Beberapa hal yang mempengaruhi perkembangan tanaman rumput laut ini misalnya lokasi budidaya, metode budidaya, bibit bermutu, managemen pengelolahan. Secara umum, bila ternya-ta presentase laju pertumbuhan harian kurang dari $3 \%$ perhari maka usaha itu tidak layak untuk dikembangkan. Dalam hal pengembangan usaha yang berhubungan dengan finansial, hasil analisis kelayakan finansial menunjukkan bahwa usaha budidaya rumput laut Kappaphycus alvarezii dengan metoda long line di perairan Karimum Jawa secara finasial menguntungkan dan layak dilaksanakan (Setyaningsih dkk. 2012). Selain itu dari sisi teknis, pada penelitian BBPBL Lampung un-tuk melihat perkembangan dan laju pertumbuhan tanaman, juga dilakukan pengamatan terhadap tingkat kelangsungan hidup dari tanaman tersebut. Data kelangsungan hidup yang diperoleh dari kegiatan perekayasaan teknologi perbanyakan bibit secara semi masal rumput laut kotoni pada kedalaman berbeda yang dapat disimak pada Tabel 3.

Pada saat sampling juga dilakukan perhitungan terhadap jumlah tanaman yang hidup tujuannya untuk mengetahui presentase tingkat kehidupan (sintasan) tanaman yang hidup. Hal ini dilakukan sebagai salah satu tolok u-kur untuk penilaian keberhasilan usaha budidaya rumput laut. Dari hasil uji coba yang telah dilakukan selama pemeliharaan tingkat kelulusan hidup rumput laut kotoni yang dipelihara pa-da kedalaman berbeda memperoleh hasil pada kedalaman $10 \mathrm{~cm}$ (98\%), $30 \mathrm{~cm}$ (96 \%) dan $50 \mathrm{~cm}$ (92\%). Data ini menunjukan bahwa tidak terjadi perbedaan yang signifikan dimana ratarata tingkat kelulusan hidup pada ketiga perlakukan tersebut. 
Hal ini mungkin saja terjadi ka-rena bibit rumput laut hasil kultur jari-ngan dari SEAMEO BIOTROP Bogor adalah bibit yang telah melalui ber-bagai seleksi kelulusan hidup. Karena menurut hasil kajian Fadel et al. (2013) yang melakukan perbanyakan bibit rumput laut dengan metoda kultur jaringan, ternyata tingkat kelu-lusan hidup calon bibit yang diha-silkan pada media kultur yang diperkaya dengan pupuk memperlihatkan pertumbuhan tunas yang lebih baik. Selain itu, kemungkinan perairan lo-kasi uji coba di BBBAL Lampung memenuhi persyaratan tumbuh untuk Kappaphycus alvarezii, khususnya pa-da nutrien yang memicu tingkat per-tumbuhan thalus dengan optimal. Kondisi ini dicermati oleh Mul-yaningrum dkk. (2012) dalam ka-jiannya tentang regenerasi filamen tha-lus rumput laut Kappaphycus alvarezii, yang menghasilkan bahwa pengaturan formulasi zat pengatur tum-buh (ZPT) yang sesuai, merupakan faktor yang menentukan regenerasi filamen thalus menjadi tunas. Dalam hal ini, digunakan ZPT indole acetic acid.

\section{SIMPULAN DAN SARAN}

Berdasarkan hasil uji coba pengaruh kedalaman berbeda terhadap perkembangan rumput laut kotoni (Kappaphycus alvarezii) hasil kultur jari-ngan maka beberapa kesimpulan yang dapat diambil: (a) pada kedalaman 10-30 cm dari permukaan air, perkemba-ngan tanaman cukup baik dengan laju pertumbuhan harian masing-masing 5\% dan 4 \% perhari. Hal ini terjadi ka-rena pada kedalaman tersebut, posisi tanaman lebih dekat ke pemukaan air sehingga sinar matahari yang dite-rimapun lebih baik dan memberi pe-ngaruh lebih baik pula pada kedua perlakuan tersebut dibanding perla-kuan tiga yaitu kedalaman $50 \mathrm{~cm}$; (b) tingkat kelulusan hidup (SR) dari ketiga perlakuan sangat tinggi yaitu lebih dari $90 \%$. Tingginya tingkat ke-lulusan hidup (SR) ini terjadi karena pada saat uji coba tanaman tidak ter-kena serangan penyakit. Selain itu selama masa uji coba dilakukan pengontrolan setiap hari sehingga tanaman terhindar dari serangan hama.

\section{PERSANTUAN}

Penulis menyampaian ucapan terima kasih kepada Pimpinan Balai Besar Pengembangan Budidaya Laut Lampung (BBPBL) yang telah mem-berikan kesempatan bagi penulis untuk melakukan penelitian ini. Juga terima kasih untuk dukungan staf Tim Laboratorium Kesehatan Lingkungan pada BBPB Lampung.

\section{DAFTAR PUSTAKA}

Aris M. 2011. Identifikasi, patoge-nisitas bakteri dan pemanfaatan gen 16srRNA untuk deteksi pe-nyakit ice- 
ice pada rumput laut (Kappaphycusalvarezii). Diser-tasi.

Sekolah Pascasarjana, Ins titu Pertanian Bogor. 126 hal

Budiyani FB, K Suwartimah, S Sunar-yo. 2011. Pengaruh pertambahan nitrogen dengan konsentrasi yang berbeda terhadap laju pertumbuhan rumput laut Caulerpasp. Diponegoro Journal of Mari-ne Reseach 1(1): 10-18.

Direktorat Jenderal Perikanan Budidaya. 2008. Petunjuk Teknis Budidaya Laut Rumput Laut Eucheuma spp. Direktorat Produksi, Direktorat Jenderal Perikanan Budidaya. Departemen Kelautan dan Perikanan. Jakarta

Fadel AH, GS Gerung, E Suryati, IFM Rumengan. 2013. The effects of stimulant growth hormones on tissue culture of seaweed Kappaphycus alvarezii in vitro. Aqu-atic Science \& Management I: 77-84. Mei 2013 .

Harahap F. 2010. Budidaya rumput dengan spora dan kultur jaringan untuk peningkatan pendapatan keluarga. Jurnal Pengabdian kepada Masyarakat, 16(62): 38-45

Mulyaningrum $\mathrm{SRH}, \mathrm{H}$ Nursyam, $\mathrm{Y}$ Risjani, A Parenrengi. 2012. Regenerasi filamen kalus rumput laut Kappaphycus alvarezii de-ngan formula zat pengatur tum-buh yang berbeda. Jurnal Pene-litian Perikanan, 1 (1): 52-60

Pongarrang D, A Rahman, Wa lba. 2013. Pengaruh jarak tanam dan bobot bibit terhadap pertum-buhan rumput laut (Kappap-hycus alvarezii) menggunakan metode vertikultur. Jurnal Mina Laut Indonesia, 3 (12): 94-112, 2013

Runtuboy N. 2008. Teknologi Bu-didaya Rumput Laut Euchema cottonii. Balai Besar Pengem-bangan Budidaya Laut Lam-pung. 25 hal.

Setyaningsih H, K Sumantadinata, NS Palupi. 2012. Kelayakan usaha budidaya rumput laut Kappaphycus Alvarezii dengan metode longline dan strategi pengembangan di Perairan KarimumJawa. Manajemen IKM, 7(2): 131142

Serdiati N, IM Widiastuti. 2010. Pertumbuhan dan produksi rumput laut Eucheuma cottonnii pa-da kedalaman penanaman yang berbeda. Media Litbang Sulteng III (1): 21-26 Mei 2010

Soenardjo N. 2011. Aplikasi budidaya rumput laut Euchema cottonii (Weber van Bosse) dengan metode jaring lepas dasar (net bag) model Cidaun. Bulletin Oseanografi Ma-rina 2011, 1: 36-44 
Susilowati T, S Rejeki, Eko, Nur-cahya, Zulfiriani. 2012. Pe-ngaruh kedalaman terhadap pertumbuhan rumput laut (Eu-cheuma cottonii) yang dibu-didayakan dengan metode long-line di Pantai Mlonggo, Kabu-paten Jepara. Jurnal Saintek Pe-rikanan, 8(1): 712 